\title{
Measuring The Usefulness Of Information For Investors' Inferences: The Case Of Quarterly Earnings Announcements
}

C. Catherine Chiang, Elon University, USA

Yaw M. Mensah, Rutgers University, USA

\begin{abstract}
In this paper, we propose a new method for assessing the usefulness of information, its inferential value. In the context of accounting and finance, we define the inferential value of information about a firm as how efficaciously the information enables investors to draw correct inferences regarding its future financial performance. On the basis of this definition, we develop a stylized model to measure the proximity of a firm's future realized rates of return to the estimated rates of return implied by its current stock price. We then use the new measure to test the hypothesis that quarterly earnings announcements have a higher inferential value than other information arriving during interim (non-earnings announcement) periods. Our empirical findings suggest that investors are able to make more informative inferences about a firm's future profitability based on quarterly earnings announcement than based on information available during interim periods. However, our findings also suggest that, in general, investors do not correctly anticipate future losses. Finally, we find that earnings announcements are as important in anticipating future profitability for larger firms as they are for smaller firms.
\end{abstract}

Keywords: Inferential value; Information sources; Investor reaction; Quarterly Earnings

\section{INTRODUCTION}

$\mathcal{G}$ $\mathrm{n}$ this paper, we propose a new method for evaluating the usefulness of a piece of new accounting information for its recipients, its inferential value. We define the inferential value of an information signal as how accurately the information allows recipients to project the long-term implications of the signal received. In the context of accounting and finance, the inferential value of information becomes a means for assessing how efficaciously investors are able to use the information to draw correct inferences about a firm's future profitability.

A frequent theme of accounting research since the early 1970s has been mapping the correspondence between capital market-based data and accounting data. The primary concern of this line of research has been whether accounting numbers are relevant to market participants, and if so, how much of the information they contain is compounded into stock and bond prices. It remains an open question whether the inferences drawn from the available data are, in fact, unbiased predictors of future firm performance. If equity securities are rationally priced, their prices comprise the present value of all future projected economic earnings (or net cash flows). This implies that rational equity pricing requires a focus on long-term forecasts of economic profitability. Thus, regardless of whether and how much a specific piece of information is compounded into price in the short term (five to ten days with event studies and one year with association studies), it is also important to evaluate how effective an information signal in actually helping investors make correct inferences concerning long-run performance implications (inferences). In this paper, we study the usefulness of financial information by assessing its capacity to help investors make inferences about this long-term performance.

In our view, an information signal has a high (low) inferential value when the estimated rate of return implied from the current price of a firm closely matches (deviates greatly from) the firm's future realized rate of 
return. Empirically, we use the residual income model (RIM), the given price, and an estimated cost of capital to compute a market-based estimate of the future Return on Equity (ROE). Given this estimated ROE, we examine how well it predicts actual future ROE values.

The study adds to the quality of the financial-reporting literature by introducing an innovative way of measuring the usefulness of financial information. It has been well documented in the price-leading-earnings literature that traditional returns-earnings regressions render as downward biased the earnings response coefficients and reduce the explanatory power of the regressions (see Kothari, 2001 for a review). The inferential value measure developed in this study offers an advantage over the traditional returns-earnings model in assessing the usefulness of accounting information. In the presence of the prices-leading-earnings phenomenon, the traditional returns-earnings regression model fails to capture all value-relevant adjustments investors are able infer and compound into the price based on the earnings information released. By contrast, the inferential-value model measures implicit rates of return which already factor in price within the measure thereby making it a richer index for assessing the extent to which announced earnings are informative.

The inferential-value measure we develop has the potential for extensive empirical application. For example, it can be used to study the inferential value of any news or newly-mandated disclosures. In studying the economic consequences of different accounting policies, the inferential-value measure can provide insights into which accounting method allows investors to make more accurate long-run inferences about the profitability of firms.

To demonstrate the empirical use of the inferential-value measure, we show how such a measure can be employed to test the hypothesis that quarterly earnings announcements provide investors with higher inferential values than other sources of information that arrive at non-quarterly announcement points.

In the sections that follow, we first present the conceptual model used to evaluate the inferential value of information signals to the capital market. The sample selection and other methodological issues are then discussed in Section 3. The performances of the models used to assess inferential values are evaluated in Section 4 and we report the results of robustness tests in Section 5. Our conclusions are provided in the final section.

\section{DATA AVAILABILITY}

The data used in this study are available from the sources identified in the paper.

\section{A STYLIZED MODEL TO ASSESS THE VALUE OF INFORMATION SIGNALS TO THE CAPITAL MARKET}

\section{A Conceptual Model for Assessing Inferential Value}

Assume that the principal objective of investors is to identify firms with the greatest rate of return on investment. In an efficient market, stock price at any given point in time reflects the investors' estimated future economic profits based on information signal received at that time. Let $\Pi_{t}^{s}$ represents the estimated economic profits based on information signals s received at time t. Let $\Pi_{t}{ }^{2}$ represents future realized economic profits. We may write the relationship between the estimated future economic profits and the future realized profits as:

$$
\Pi_{t}{ }^{R}=\gamma_{t} \Pi_{t}{ }^{s}
$$

In this framework, an information signal attains its highest achievable inferential value when $\Pi^{s}=\Pi^{R}$ (i.e., when investors have perfect foresight). In such a case, the value of $\gamma_{t}$ is one. Therefore, the closer $\gamma_{t}$ is to one, the higher the information's inferential value. Note that $\gamma_{t}$ in Equation (1) denotes the inferential value of the 
information set $s$. Stated differently, the desirable information set $s^{*}$ is one that satisfies the following condition: $\left|1-\gamma_{t}^{s^{*}}\right| \rightarrow 0$, where $|$.$| is the absolute value operator.$

On the basis of above definition, we can compare the inferential value of two information signals $s 1$ and $s 2$. As gammas $(\gamma)$ could be above or below one, we discuss the incremental inferential value under all possible conditions. First, if both gammas are less than one but greater than zero, $0<\gamma_{s 1}, \gamma_{s 2}<1$, a statistically significant positive difference of $\gamma_{s 2}-\gamma_{s 1}$ would indicate that the information set $s 2$ has greater inferential value than the information set $s 1$. In this case, a direct test for the incremental inferential value of the information set $s 2$ over $s 1$ can be performed using the standard F-test for the difference in coefficients from two regression equations. Secondly, if both gamma values are greater than one, $\gamma_{s 1}, \gamma_{s 2}>1$, the lower of the two values has incremental inferential value. Finally, in the hybrid case where one of the two gammas is greater than one and the other is less than one, an increase in inferential value can be deduced from their relative proximity to one. If both are equidistant from one, the two information sets have the same inferential value. In all cases, the incremental inferential value of information set $s 2$ over $s 1$ can be represented mathematically as:

$$
\left|1-\gamma_{t}^{s 1}\right|-\left|1-\gamma_{t}^{s 2}\right|
$$

Similarly, assuming information arrives sequentially at $t$ and $t+1$, the incremental inferential value of the information value at time $t+1$ over the one at time $t$ can be written as:

$$
\left|1-\gamma_{t}\right|-\left|1-\gamma_{t+1}\right|
$$

Finally, in a cross-sectional context, a negative gamma term would imply that capital markets draw an inference from the information set opposite to the realized effect.

\section{Derivation of an Empirical Inferential Value Measure in the RIM Framework}

Recall that in section 2.1 above, we set out to measure the inferential value $\gamma_{t}$ by relating the estimated economic rates of return to the future realized rates of return. In this section, we derive the implicit economic rate of return under the Residual Income Model (RIM) framework and go on to discuss different ways to measure inferential value empirically by relating the implicit rates of return to future realized returns. We then explain why we select the regression method to measure inferential value.

When a new piece of relevant information is available to the market, investors will reassess the value of a firm using it as the basis. Using the stock price, we can then derive an implicit rate of return. In the RIM framework, the value of a firm is the sum of its current book value and the present value of its future abnormal earnings, which can be written as:

$P^{s}{ }_{0}=B V_{i 0}+\sum_{t=1}^{\infty} \frac{\left(r_{t}^{E}-k_{t}\right) B V_{t}}{\left(1+k_{t}\right)^{t}}$

where $P_{0}^{s} \quad=$ stock price of the firm $i$ based on information set $s$ available at time 0 ;

$\mathrm{r}_{\mathrm{t}}^{\mathrm{E}} \quad=$ expected rate of return on equity of firm $i$ in future periods $\mathrm{t}(\mathrm{t}=1,2, \ldots ., \mathrm{T}) ;$

$k_{i 0} \quad=$ cost of capital or required rate of return on book value of firm $i$ estimated at base period 0 ;

$B V_{t} \quad=$ estimated book value of firm $i$ shareholders' equity at future period t. 
Assuming that $\mathrm{k}$ (the cost of capital) is constant over the investment horizon and that future growth is constant and can be impounded in $\mathrm{r}^{\mathrm{E}}$, : we derive the implicit rate of return based on information available at time 0 as:

$r_{1}^{E}=k_{0}+\frac{k_{0}\left(P_{0}^{s}-B V_{0}\right)}{B V_{1}}$

where $r_{1}^{E} \quad=$ the implicit rate of return on equity;

$\mathrm{BV}_{1}=$ the book value of equity projected for the firm at the end of the next accounting period;

$\mathrm{BV}_{0} \quad=$ the book value of equity last reported for the firm.

To gauge the inferential value of any information signal, we can imagine fast forwarding the clock to the future (which is already known) to obtain the "future" realized rate of return of this firm. We can then compare this future rate to its implicit rate of return derived from the RIM as in Equation (4). As explained in section 2.1 above, a desirable information signal is the one that results in a close match between the implicit rate of return and the future realized rate of return. Closeness of the future realized rate of return to the firm's implicit rate of return at time 0 would then indicate the "correctness" of the inference made by means of the information signal. To show how we quantify the closeness of the two rates, consider the following alternatives: (1) calculate the difference between the two rates; (2) calculate the ratio of one rate to the other; or (3) perform a regression of the realized rates of return on the implicit rates of return and use the coefficient as an inferential-value indicator. Given that there exist factors which may affect the relationship between these two rates but have nothing to do with the inferential value of the information, we adopt the regression method. We do so because it yields a more precise measure of the closeness of the two rates by setting the confounding factors as control variables.

\section{HYPOTHESIS TESTING USING THE INFERENTIAL-VALUE MEASURE}

In this section, we use the inferential-value method derived in Section 2 above to test the hypothesis that quarterly earnings announcements enable investors to make improved inferences about a firm's future performance when compared to other sources of information arriving during interim periods.

We recognize that accounting reports are not the sole source of information for investors and that alternative sources of information are frequently more timely than the quarterly financial statements. ${ }^{1}$ In spite of a plethora of data available from non-financial statement sources, there is a continuing demand for accounting information. This rests on the fact that financial statements provide a more definitive basis for capital markets when performing reality checks on previous assumptions and expectations. They do so by compelling investors to recalibrate their estimates of the implications of various economic scenarios for a given firm's most probable future earnings capacity.

This view of the role of accounting information leads to the hypothesis that price reactions to quarterly earnings announcements should be more highly associated with long-term future profitability assessments than similar reactions to information from other sources. In this view, price reactions to information released in nonearnings announcement periods are attempts by capital markets to formulate projections of future firm performance based on the relationships estimated since the last earnings release. Given that dynamic changes occur in the environment, a Bayesian revision of the prior probabilities attached to these expected relationships is undertaken when accounting data later released tends to confirm or modify investors' prior beliefs. Here we contend that such data released during non-earnings announcement periods have a lower inferential value when compared to accounting data, at least with respect to the long-term future earnings potential of the firm. As an example, consider

\footnotetext{
${ }^{1}$ Among these alternative information sources are statistical data such as the semiconductor industry's book-to-bill ratio and the retail industry's same-store sales data, as well as more general survey data such as the University of Michigan's Index of Consumer Sentiment. In addition, commodity price indices, yields on short- and long-term debt instruments, inflation indices, and other diverse statistics released by Federal agencies and private organizations on a continuing basis.
} 
the market price reaction to news of the sudden resignation of a firm's chief executive officer. A consequent significant price movement implies that investors have reassessed the probability distribution of the future profits of the firm. The real issue in the present context is whether such a price reaction has any inferential value. ${ }^{2}$

Given our objective of testing the incremental inferential value of other sources of information relative to quarterly reports, we specify the following four points in time as pertinent (see Exhibit 1):

1. $\quad$ the first trading day of the current fiscal quarter (denoted as BQ);

2. two days before the release of last quarter's earnings (denoted as EAD-2);

3. two days after the release of last quarter's earnings (denoted as EAD+2)

4. $\quad$ the last trading day of the current fiscal quarter (denoted as EQ).

The earnings announcement period from 2 days before (EAD-2) to 2 days after $(E A D+2)$ the earnings announcement date is labeled period 0 . The period from the beginning of the quarter (BQ) to EAD-2 is labeled period -1 and the period that runs from $\mathrm{EAD}+2$ to end of the quarter (EQ) is labeled period 1. A schematic representation of the critical dates at which the implicit rates of return (ImpROEs) are measured is presented in Exhibit I. Note that the ImpROE computed at each date is expected fully to reflect whatever information is publicly available at the time. Therefore, changes in the inferential value of ImpROEs computed at these dates should enable us to evaluate the inferential value of the quarterly earnings announcements relative to other information sources. Although other valuation-relevant data may be released during the five-day period surrounding the release of a quarterly report, we assume that price reactions around this period (subinterval 0 ) are principally responses to that quarterly report. Price movements during periods -1 and 1 (before and after the earnings announcement) are presumed to be reactions to non-accounting information disclosures.

To render operational the proposed test using the regression method, we adopt the following model:

$$
\begin{aligned}
& \operatorname{ROE}_{Y}=\alpha_{0}+\alpha_{1} \text { FINANCE }+\alpha_{2} H_{-} I_{-} \text {ECH }+\gamma_{1} \operatorname{ImpROE}_{B Q}+\gamma_{2}\left(\Delta \operatorname{ImpROE} E_{E A D-2}\right) \\
& +\gamma_{3}\left(\Delta \operatorname{ImpROE_{EAD+2}}\right)+\gamma_{4}\left(\Delta \operatorname{ImpROE_{EQ}}\right)+\gamma_{5} B T M+\gamma_{6} \operatorname{SIZE}+e
\end{aligned}
$$

where

$R O E_{Y}=\quad$ average accounting return on equity defined over $\mathrm{Y}$ future periods (including the rate of return in the current quarter not yet known);

FINANCE = dummy variable for financial firms;

HI-TECH = dummy variable for high-technology firms (as defined in Francis \& Schipper, 1999);

$\operatorname{ImpROE}_{B Q}=$ implicit rate of return computed using Equation (8) based on the stock price on the first trading day of the current fiscal quarter;

ImpROE $E_{E A D-2}=$ implicit rate of return computed from the stock price two trading days before the quarterly earnings announcement;

\footnotetext{
${ }^{2}$ One advantage of the method developed here is that it is possible to examine the inferential value of the price reaction to unanticipated news of this sort. If a sufficient sample of such announcements can be gathered, the ability of capital markets correctly to apply the implications of such news can be evaluated regardless of their timing. For example, it would be possible to compare the inferential value of monthly data, such as the retail industry's same-store sales data, with quarterly earnings announcements.
} 
ImpROE $E_{E A D+2}=$ implicit rate of return computed from the stock price two trading days after the quarterly earnings announcement;

$\operatorname{ImpROE_{EQ}}=$ implicit rate of return computed from the stock price on the last trading day of the quarter,

$$
\begin{aligned}
& \triangle \operatorname{ImpROE_{EAD-2}}=\operatorname{ImpROE_{EAD-2}-\operatorname {ImpROE}}{ }_{B Q} ; \\
& \triangle \operatorname{ImpROE} E_{E A D+2}=\operatorname{ImpROE_{EAD+2}-\operatorname {ImpROE}} E_{E A D-2} ;
\end{aligned}
$$$$
\triangle \operatorname{ImpROE} E_{E Q}=\operatorname{ImpROE}_{E Q}-\operatorname{ImpROE}_{E A D+2}
$$

$\mathrm{BTM}=\quad$ book-to-market price ratio;

SIZE $=\quad$ size of the firm as measured by the natural log of market capitalization at the beginning of the quarter.

In this model, four control variables are considered. The first two, FINANCE and HI-TECH, represent expected specific-industry effects. FINANCE is a dummy variable for financial institutions (SIC code between 6000 and 7000). Given the increased trend towards "mark-to-market" accounting over the last two decades, the book values of the assets of financial institutions are more likely to reflect their current market values. As a consequence, the relationship between ImpROEs and ROEs for financial institutions is expected to be closer to unity than is the case for firms in other industries. This leads to the expectation that the FINANCE dummy will have a positive coefficient.

HI-TECH, the other dummy variable, represents high-technology firms identified using the approach in Francis and Schipper (1999). As Lev and Zarowin (1999) observe, the systematic allocation of such outlays as research and development costs to expenditures by high-technology firms leads to the exclusion of some significant intangible assets from their accounting records. The result is that the book values of the assets of these firms are expected to be systematically understated (relative to their market values) in a cross-sectional context. This leads to the expectation that the HI-TECH dummy will have a negative or insignificant coefficient.

Two other control variables were added to the regression in Equation (4) as proxies for the information environment: the firm size (SIZE) as measured by total market capitalization at the beginning of the current quarter and the book-to-market price ratio (BTM). As larger firms tend to have more analysts following the market for their securities, it can be presumed that they operate in a richer information environment. Such an environment should translate into investors anticipating future profitability with greater accuracy leading to the expectation that SIZE will have a positive coefficient. Similarly, BTM is expected to be positively related to future profitability because firms with high BTM ratios are typically valued conservatively by investors. As demonstrated by Fama and French (1992, 1995), high BTM firms tend to outperform low BTM firms in the long run, presumably because such BTM ratios are proxies for unknown market risk factors.

An evaluation of the incremental inferential value of information released after the start of the fiscal quarter can be carried out on the basis of the positive signs and statistical significance of $\gamma_{2}, \gamma_{3}$, and $\gamma_{4}$ in Equation (4).

The first differences of the ImpROEs were taken sequentially in Equation (4) to deal with the high degree of multicollinearity that would be likely to exist if the original ImpROEs themselves were used in the regression. The effectiveness of the approach adopted is supported by the greatly reduced variance inflation factors (reported in Table 2) computed for Equation (4) as compared to an alternative formulation where the levels of the ImpROEs for all four periods were used in the regression. 


\section{EXHIBIT 1}

Implicit Market Rate of Return (ImpROE) variables in relation to Quarterly Earnings Announcement Timeline

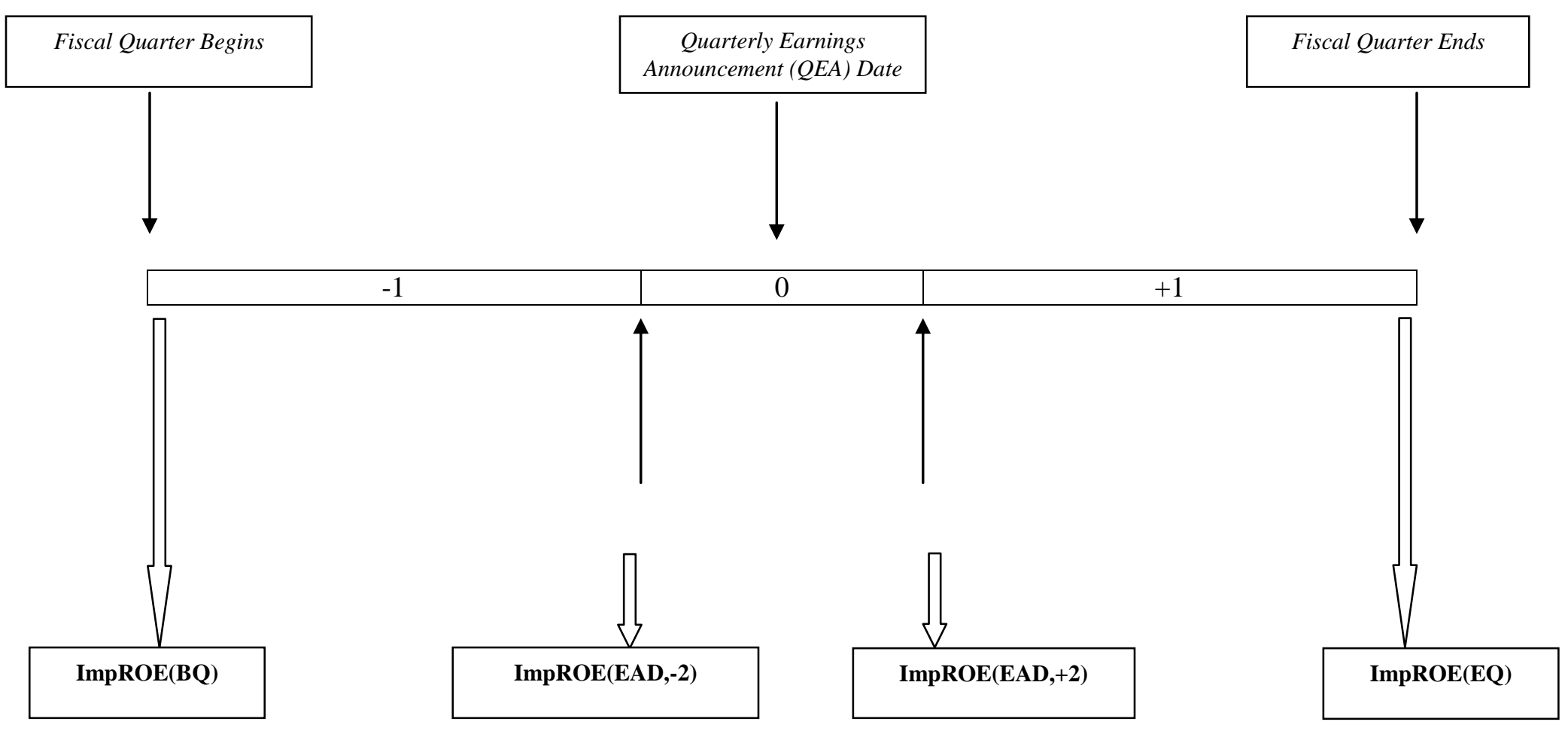




\section{Operational Measurement of Dependent Variables}

We chose longer forward ROE intervals for our empirical testing of the model because there is now sufficient empirical evidence to conclude that the extent to which accounting earnings can be considered informative increases as the contemporaneous association interval is lengthened (Easton, Harris, and Ohlson, 1992). ${ }^{3}$ As the reporting interval is lengthened, the measurement error in the accounting accrual process decreases, as does the difference between cash flows and accounting earnings.

Since the ROEs are measured across overlapping periods, a pooled cross-sectional approach cannot be used because the dependent variable observations for individual firms would not be independent of those in later quarters. To avoid this problem, we adopted an approach suggested by Doyle, Lundholm, and Soliman (2003). Essentially, we estimated Equation (1) for each quarter-year separately and went on to derive the mean of the resulting coefficient estimates. Using the Fama-McBeth t-statistic approach, we computed the traditional standard error and then applied the Newey-West correction (Verbeek, 2000, p. 104).

The forward ROEs were computed by averaging all the quarterly earnings of the firm for all quarters ahead (including the current one) and dividing by the book value reported for the previous quarter (at the earnings announcement date, EAD, that is the focus of the current quarter). The result was multiplied by four to obtain the annualized ROE. As an alternative and to provide for a robustness check, we also derived the quarterly ROEs by dividing each forward quarter's earnings by the previous quarter's book value, averaging these ROEs for the relevant future periods of 4,12 , and 20 quarters ahead. The results obtained were qualitatively similar to those reported here.

\section{Operational Measurement of Independent Variables}

To derive the ImpROE terms, it is first of all necessary to estimate the cost of capital (or required rate of return, $k_{0}$ ) at the four dates of interest: $\mathrm{BQ}, \mathrm{EAD}-2, \mathrm{EAD}+2$, and EQ. Given the considerable accumulated empirical evidence indicating that the Capital Asset Pricing Model (CAPM) is mis-specified, at least with respect to firm size and price-to-book ratios (Fama \& French, 1992, 1995; Kim, 1995), we decided to estimate the cost of capital using the model proposed by Ohlson and Juettner-Nauroth (2005). Empirical evidence presented by Gode and Mohanram (2003) indicates that this model produces cost of capital estimates that outperform both the CAPM-based measure and the residual-income-based measure proposed by Lee, Myers, and Swaminathan (1999) in its relationship to benchmark indices, such as leverage, risk premium, and earnings variability. Following Gode and Mohanram (2003), we calculate the cost of capital by setting the growth rate of the firm equal to 4\%, the long-run estimated growth rate of the US economy. However, we substituted analysts' long-run (five years) earnings growth forecasts for the two-period-ahead forecast in the model. The primary reason for doing so was that this substitution allowed for a larger sample size, for otherwise, firms for which the first-year forecast was negative would have had to be omitted. Moreover, the estimates of the implied cost of capital obtained by means of the substitution of analysts' long-run growth forecasts for the shorter-term one appeared to be more realistic (for example, fewer negative values). The cost of capital was estimated at the beginning of each year and used throughout all quarters of that year.

\footnotetext{
${ }^{3}$ As rates of return on equity have been found to be mean-reverting for most firms (see, for example, Foster, 1977 and Ou and Penman, 1989), an arithmetic average of quarterly rates of return computed over some future time interval should suffice as an indicator of the earning power, investment opportunity set, and growth opportunities of firms. This assumes that firms attempt to optimize shareholder wealth by choosing the least costly form of financing when confronted with profitable investment opportunities.

${ }^{4}$ The adjusted standard error derived from the Newey-West correction for possible serial correlation can be described as: Adjusted standard error $=$ Traditional standard error $*\left[1+\sum_{i=1}^{n}\left(1-\frac{i}{n+1}\right) \rho_{i}\right]^{1 / 2}$

where $\rho_{I}=$ the autocorrelation at lag $i$ and $n=$ number of lags expected to be autocorrelated.

For this study, $\mathrm{n}$ was set equal to the number of future quarters over which ROE was computed minus one. Thus, for the ROE $1 \mathrm{YR}$ , $\mathrm{ROE}_{3 \mathrm{YR}}$, and $\mathrm{ROE}_{5 \mathrm{YR}}$ settings, $\mathrm{n}$ was set equal to 3,11 , and 19 respectively.
} 
To derive $\mathrm{BV}_{1}$ for $\mathrm{BQ}$ and $\mathrm{EAD}-2$, the consensus analysts' forecast of earnings per share of the past quarter less the current dividends per share was added to $\mathrm{BV}_{0}$ (the last reported book value per share of equity). For $\mathrm{BV}_{1}$ in $\mathrm{EAD}+2$ and $\mathrm{EQ}$, the consensus earnings forecast at the respective month-ends for the current quarter and the current quarter's dividends to be paid were used to adjust the book value per share reported at the quarterly earnings announcement $\left(\mathrm{BV}_{0}\right)$. As a result, $\mathrm{ImpROE}_{\mathrm{EAD}+2}$ and $\mathrm{ImpROE}_{\mathrm{EQ}}$ reflect the most recent accounting and analysts' forecast information.

\section{Sample and Data Sources}

All earnings forecast data were obtained from the IBES Summary Forecast database. Stock prices are obtained from CRSP, with an adjustment for stock dividends and stock splits occurring during the relevant subintervals. All accounting data, including the quarterly earnings release dates, were made available in the Compustat quarterly database. In cases where the quarterly earnings announcement dates were not available through Compustat but could be found on the IBES database, the latter source was used instead.

The sample period runs from 1985 to 2005 , with an initial sample of 360,427 firm-quarter observations drawn from Compustat. Since ImpROEs cannot be computed for firms with negative book values, 14,010 firmquarters were omitted. The requirement to have both two-year-ahead annual earnings forecasts as well as long-term growth estimates from IBES, together with the merger with CRSP, resulted in a maximum sample size of 193,798 firm-quarters.

\section{RESULTS OF THE ROE TESTS}

\section{Summary of Sample Characteristics}

A summary of the key characteristics of the sample is presented in Table 1, with the results pooled across all quarters. To deal with possible outliers, all the variables except SIZE have been winsorized at the high and low ends of 1 percent and 99 percent, respectively. The results were not affected when the winsorization cutoff was set at 5 and 95 percent, respectively. Also, all firm-quarters with negative book values were deleted from the sample because for these cases, the ImpROE values could not be computed. Similarly, as firms with negative book values over the relevant period were omitted, the negative ROEs computed were derived only from firms with future losses.

For the sample as a whole, the ImpROEs ranged from 0.02 to 2.21 , with a average of about 0.28 for all three versions. By contrast, $\mathrm{ROE}_{\mathrm{Y} 1}$ had a mean of 0.07 , and a range from -1.56 to 1.21 . This range changed minimally as the period over which the ROEs were calculated was lengthened, with the mean for $\mathrm{ROE}_{\mathrm{Y} 3}\left(\mathrm{ROE}_{\mathrm{Y} 5}\right)$ at $0.10(0.13)$ and the range from $-1.37(-1.52)$ to $1.22(1.40)$, respectively. The median market capitalization of the firms in the sample over the 20 -year period was $\$ 287$ million, with the range being from $\$ 2$ million to $\$ 586$ billion. The book-to-market price ratio over the same period had a mean of 0.64 and a range from 0.05 to 2.69. Finally, approximately 15 percent of the sample observations were from financial firms and 18 percent were from hightechnolgy firms.

Overall, the estimated ImpROEs proved to be approximately twice the magnitude of the future ROEs in the total sample. A possible reason for this upward bias (relative to ROE) in the ImpROEs is that the book values (which appear as a denominator in the ImpROE equation) were biased downwards because of the accounting conservatism principle. ${ }^{5}$ The ratio of price to a downwardly biased book value will have a pronounced effect on ImpROE and a relatively minor effect on $R O E$ since the earnings numerator in that ratio will be subject to the same accounting bias as the book value.

\footnotetext{
${ }^{5}$ Specifically, book values may be severely understated compared to their current replacement costs. Thus, the price-to-book value ratio would be overstated compared to their equivalent Tobin's q (i.e., the ratio of market value of equity to the replacement cost of net assets). See Tobin (1969) and Wernerfelt and Montgomery (1988) for a discussion of the economic role of Tobin's q at the macroeconomic and the microeconomic levels.
} 


\section{Dealing with Multicollinearity}

As an effective way to mitigate the potential impact of multicollinearity among $\operatorname{ImpROE}_{\mathrm{BQ}}$, $\operatorname{ImpROE}_{\mathrm{EAD}-2}$, ImpROE $_{\mathrm{EAD}+2}$, and $\operatorname{ImpROE}_{\mathrm{BE}}$, we used as change variables the variations in the ImpROE values over the three intervals (periods $-1,0,1)$ during the course of each quarter. Table 2 presents the multicollinearity-related statistics and provides the justification for using these change variables. Panel A presents the variance inflation factors (VIFs) observed when the original four ImpROE variables were used in Equation (9) instead of the change variables. Note that the VIFs for the four original variables exceed the rule of thumb for VIFs that they should be below 10.0 (Belsely, Kuh, and Welsch, 1980). By contrast, when the change variables ( $\triangle \operatorname{ImpROE}_{E A D-2}, \triangle I m p R O E_{E A D+2}$, and $\triangle \operatorname{ImpROE} E Q$ ) were used, the VIFs drop to below 2.0.

Panel B of Table 2 establishes essentially the same point. Using pairwise Pearson correlation coefficients, it can be observed that the correlations between the original ImpROE variables are all above 0.73 . By contrast, when the change variables were used, the product moment correlations drop to below an absolute value of 0.20 .

One noteworthy result in Panel B relates to the magnitude of the correlation coefficients between the ROE and the ImpROE measures. In the aggregate sample, the pairwise correlation coefficients are all very small (ranging from -0.03 to 0.04 ). Given these surprisingly small correlation values, the sample was divided into POSITIVE ROE and NEGATIVE ROE firms. The estimated pairwise correlation coefficients between the ROE and ImpROE values changed significantly with this subdivision of the sample. The results of this procedure are presented in Table 3 .

The results in Table 3 show that the correlation coefficients between ROE and ImpROE in the POSITIVE ROE sample are all positive and hover around 0.40 . The coefficients are higher for $\mathrm{ROE}_{\mathrm{Y} 1}$ than for $\mathrm{ROE}_{\mathrm{Y} 3}$, and these are also higher than for $\mathrm{ROE}_{\mathrm{Y} 5}$. Thus, as might be expected, forecasts of firm profitability inferred from the ImpROEs are more accurate in the near term (one-year-ahead forecasts) and grow progressively weaker as the forecast interval is lengthened. In a similar vein, the correlations of the alternative ImpROE measures with the ROE measures increase as the end of the fiscal quarter nears. Interestingly, the biggest jump in the pairwise correlations occurs in the five-day period surrounding the earnings announcement, that is, from ImpROE $E_{E A D-2}$ to ImpROE $E_{E A D+2}$. For example, for $\mathrm{ROE}_{\mathrm{Y} 1}$, the correlation coefficient increases from 0.450 with $\operatorname{ImpROE}_{\mathrm{BQ}}$ to 0.453 with

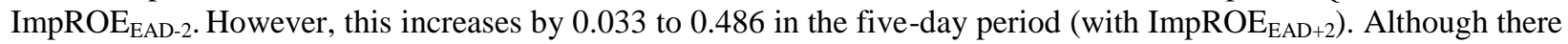
is a further increase of 0.017 to 0.503 by the end of the fiscal quarter, the average time interval over which this increase occurs is 30 days.

The results commented on above are partially reversed in the NEGATIVE ROE sample. The correlation coefficients in this case are all negative, implying that investors do not correctly anticipate the unprofitability of the firms, particularly where the unprofitability is to occur in the more distant future. The negative correlation coefficients between the more distant ROE intervals $\left(\mathrm{ROE}_{\mathrm{Y} 3}\right.$ and $\left.\mathrm{ROE}_{\mathrm{Y} 5}\right)$ and ImpROEs are higher than those between the one-year-ahead ROE and ImpROEs. At the same time, the increase in the negative coefficients is highest around the five-day period from EAD-2 to EAD+2. For example, for $\mathrm{ROE}_{\mathrm{Y}}$, the correlation coefficient increases from -0.243 at $\operatorname{ImpROE}_{\mathrm{EAD}-2}$ to -0.316 at $\operatorname{ImpROE}_{\mathrm{EAD}+2}$, while the movement to $\mathrm{ImpROE}_{\mathrm{EQ}}$ involves only an increase to -0.318 .

In summary, as the analysis presented in Table 3 supported the inference that future unprofitability is not correctly anticipated by investors, a separate analysis of the POSITIVE ROE and NEGATIVE ROE firms was necessary.

\section{Prediction of Future Accounting Profitability}

Darrough and Ye (2007) and McCallig (2003) have shown that the valuation of loss firms differs systematically from that for profitable firms. For this reason, and as a result of the analysis above, we present the estimation of Equation (9) separately for profitable firms and loss firms. Furthermore, because the first quarter of each year is the period when the final year-end results of the previous fiscal year are presented, an analysis of the first quarter is of special interest. Table 4 presents the results of estimating Equation (4) using these first fiscal quarter observations. 
Panel A of Table 4 presents the results for the POSITIVE ROE sample for the one-year-ahead, three-yearahead, and five-year-ahead profitability. All the variables except SIZE are statistically significant in the one-year-

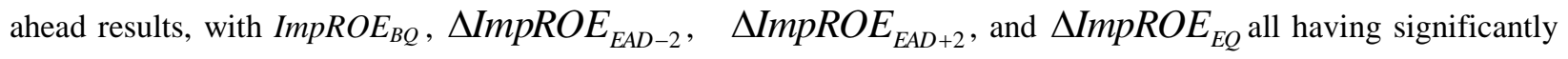
positive coefficients. Of the three change variables, $\triangle \operatorname{ImpROE}_{E A D+2}$ has the most statistically significant coefficient, suggesting that the standard error for that coefficient is the smallest. Since the ImpROE variables are based on stock prices, the size of the standards errors in the regression equations should be similar. The fact that the standard errors of the MNARRs computed two days after the quarterly announcement are the smallest in the first quarter leads to the inference that investors draw more consistently accurate inferences about future earnings from the first quarter earnings announcement than they do from information released at other times. The BTM coefficient is statistically significant and negative, implying that firms with high book-to-market price ratios are typically not as profitable from an accounting standpoint as those with low BTM ratios. As SIZE has a negative coefficient that is statistically significant in the three-year-ahead and five-year-ahead ROE estimates, smaller firms appear to be more profitable over a longer horizon than do larger firms.

Panel B of Table 4 presents the results for the NEGATIVE ROE sample. For all three forecast horizons, the significant terms (apart from the intercept) are $\operatorname{ImpROE}_{B Q}, \triangle \operatorname{ImpROE}_{E A D+2}$, and SIZE. All of the significant terms except SIZE have negative coefficients. This result supports the inference drawn earlier that long-term accounting losses are frequently not anticipated by investors, particularly when the reactions are based on annual accounting reports released during the first fiscal quarter.

In the interests of brevity, the full results for the other three fiscal quarters are not reported here in full. Instead, because the results for the fourth quarter are typical, we report those results in Table 5, with Panel A representing the POSITIVE ROE sample and Panel B the NEGATIVE ROE sample.

The results in Table 5 are essentially similar to those reported for the first fiscal quarter. In Panel A, the change variables and $\operatorname{ImpROE}_{B Q}$ are all statistically significant in all forecast periods. Of the change variables, $\triangle I m p R O E_{E A D+2}$ remains strongly significant in all periods, indicating that it has the smallest standard error compared to the other change variables. BTM and SIZE are also significant in the three-year-ahead and five-yearahead forecast periods, and their negative signs are consistent with the earlier findings.

In Panel $\mathrm{B}$ of Table 5, the negative coefficient for all three $\triangle \operatorname{ImpROE}$ variables is as expected given the previous findings. Overall, the results are consistent with the interpretation that long-term losses are correctly anticipated by capital markets or that investors are usually optimistic that loss firms can change towards profitability sooner than actually occurs in hindsight.

\section{ROBUSTNESS CHECK}

To determine how robust the results reported so far are with respect to alternative interpretations, we performed the additional test reported in this section. Specifically, we reexamined our findings taking into account firm size. We also discuss here how market inefficiency may affect the results.

\section{Firm-Size Effect}

Prior research findings suggest the hypothesis that quarterly earnings announcements may have higher inferential value for smaller firms than for larger firms (Atiase 1980, 1985; Collins et. al. 1987). That is, the more extensive non-accounting sources of information available for larger firms may provide a basis for predicting their performance over longer periods than for smaller firms. To test this hypothesis, the overall sample was divided into two groups, LARGE and SMALL, based on the median value of market capitalization for the POSITIVE ROE firms. Firms with market values above the median were designated as LARGE and those below the median as SMALL. The SMALL group consisted of firms with a market value below $\$ 1$ billion (natural log of 12.57), while the LARGE group had market values of at least $\$ 1$ billion. For the purposes of this test, we pooled the POSITIVE ROE and NEGATIVE ROE firms before the subdivision into LARGE and SMALL. 
The results of re-estimating Equation (4) for the LARGE and SMALL groups are presented in Table 6. For the sake of brevity, we present only the first quarter results for $\mathrm{ROE}_{\mathrm{Y} 1}$ since the analyses for other quarters and the prediction periods are similar

Panel A of Table 6 presents the results for the POSITIVE ROE firms. For both LARGE and SMALL firms in this case, the standard error for $\triangle I m p R R_{E A D+2}$ is relatively smaller than those for the other two change variables, resulting in the largest $\mathrm{t}$-value (and highest degree of significance). In terms of the contribution to the adjusted Rsquared, the average in the LARGE sample across all 20 years was 0.05 for $\Delta \operatorname{ImpROE}_{\mathrm{EAD}+2}$ as compared to 0.01 for $\triangle I m p R R_{E A D-2}$ and 0.03 for $\triangle I m p R R_{E Q}$. Similar results are observed in the SMALL sample. Consistently with the results of Atiase $(1980,1985)$, larger firms appear to enjoy a richer information environment, especially after the earnings announcement period, as demonstrated by the larger coefficient of $\triangle \operatorname{Imp} R R_{E Q}$ for these firms (0.320) than for smaller firms $(0.287)$. The information that arrives immediately before the earnings announcement, as represented by $\triangle I m p R R_{E A D-2}$, appears to have a higher inferential value for smaller firms (0.307) than for larger firms $(0.202$, insignificant).

Panel B of Table 6 presents the results for the NEGATIVE ROE sample. Although the average adjusted Rsquared across all 20 years was 0.244 for the LARGE sample and 0.148 for the SMALL sample, the considerable instability in the coefficients over these years is indicated by the fact that the Fama-McBeth coefficients are barely significant for any of the individual variables after the Newey-West adjustments were made. $\operatorname{ImpROE}_{\mathrm{BQ}}$ and the intercept were significant in the SMALL sample, but the other variables were not. In the LARGE sample, none of the variables appears as significant when pooled across the 20 years.

In summary, the results of this robustness test indicate that the inferential value of accounting earnings reports is relatively stable across the samples of LARGE and SMALL firms. Since the average R-squared in the LARGE group is higher than in the SMALL group, the conclusion to be drawn is that the presumed richer information environment of larger firms does not inhibit the greater inferential value of the quarterly earnings reports.

\section{How Can Market Inefficiency Affect the Results?}

The method developed in this paper assumes market efficiency. If the markets are inefficient, we should not observe any systematic relationship between future ROE and price reactions at any point in time. In the case where the market is inefficient (over- or under-reaction) in processing the quarterly earnings information, the effect will be captured at period -1 and 1, producing empirical results biased against our hypothesis. This may partially explain why the coefficients of the ImpROEs are similar in value. However, as our results demonstrate, the inferential value of information received during the earnings period is indeed higher than for that received in the non-earnings periods, thereby implying some degree of market efficiency, at least over longer-term intervals. 
Table 1

Summary Statistics of Relevent Variables

\begin{tabular}{|c|c|c|c|c|c|}
\hline Variable & $\mathbf{N}$ & Mean & Minimum & Median & Max \\
\hline $\mathrm{ROE}_{\mathrm{Y} 1}$ & 193798 & 0.07 & -1.56 & 0.11 & 1.21 \\
\hline $\mathrm{ROE}_{Y 3}$ & 176278 & 0.10 & -1.37 & 0.12 & 1.22 \\
\hline $\mathrm{ROE}_{\mathrm{Y} 5}$ & 133202 & 0.13 & -1.52 & 0.13 & 1.40 \\
\hline $\operatorname{ImpROE(BQ)}$ & 193798 & 0.29 & 0.03 & 0.19 & 2.15 \\
\hline $\operatorname{ImpROE}(\mathrm{EAD},-2)$ & 193798 & 0.29 & 0.03 & 0.19 & 2.21 \\
\hline $\operatorname{ImpROE}(\mathrm{EAD},+2)$ & 193798 & 0.28 & 0.03 & 0.19 & 1.91 \\
\hline ImpROE(EQ) & 193798 & 0.28 & 0.02 & 0.19 & 1.90 \\
\hline$\Delta \mathrm{ImpROE}(\mathrm{EAD},-2)$ & 193798 & 0.00 & -0.19 & 0.00 & 0.19 \\
\hline$\Delta \operatorname{ImpROE}(\mathrm{EAD},+2)$ & 193798 & -0.01 & -0.60 & 0.00 & 0.37 \\
\hline$\Delta \operatorname{ImpROE}(\mathrm{EQ})$ & 193798 & 0.00 & -0.38 & 0.00 & 0.31 \\
\hline BTM & 193798 & 0.64 & 0.05 & 0.54 & 2.69 \\
\hline SIZE & 193798 & 12.67 & 1.03 & 12.57 & 20.19 \\
\hline FINANCE & 193798 & 0.15 & 0.00 & 0.00 & 1.00 \\
\hline HI-TECH & 193798 & 0.18 & 0.00 & 0.00 & 1.00 \\
\hline
\end{tabular}

Variable Definitions

$\mathrm{ROE}_{\mathrm{Y} 1}=$ Return on equity computed over the next four quarters ahead (including the current quarter for which earnings will be reported in the next quarter).

$\mathrm{ROE}_{\mathrm{Y} 3}=$ Return on equity computed over the next three years ahead (including the current quarter).

$\mathrm{ROE}_{\mathrm{Y} 5}=$ Return on equity computed over the next five years ahead (including the current quarter).

$\operatorname{ImpROE}(\mathrm{BQ})=\operatorname{ImpROE}$ computed at the beginning of the current fiscal quarter.

ImpROE $(E A D,-2)=$ ImpROE computed from stock price two days before last quarter's earnings announcement in the current quarter.

$\operatorname{ImpROE}(\mathrm{EAD},+2)=\operatorname{ImpROE}$ computed from the stock price two days after last quarter's earnings announcement in the current quarter.

$\operatorname{ImpROE}(\mathrm{EQ})=\operatorname{ImpROE}$ computed at the end of the current fiscal quarter

$\triangle \operatorname{ImpROE}(\mathrm{EAD},-2)=\operatorname{ImpROE}(\mathrm{EAD},-2)-\operatorname{ImpROE}(\mathrm{BQ})$

$\triangle \operatorname{ImpROE}(\mathrm{EAD},+2)=\operatorname{ImpROE}(\mathrm{EAD},+2)-\operatorname{ImpROE}(\mathrm{EAD},-2)$

$\Delta \operatorname{ImpROE}(\mathrm{EQ})=\operatorname{ImpROE}(\mathrm{EQ})-\operatorname{ImpROE}(\mathrm{EAD},+2)$

$\mathrm{BTM}=$ Book-to-market price ratio measured at the beginning of the current quarter.

SIZE $=$ Size of the firm measured by market capitalization at the beginning of the quarter.

FINANCE $=$ Dummy variable for financial institutions

HI-TECH= Dummy variable for high-technology firms (as defined by Francis \& Schipper (1999)). 
Table 2

Variance Inflation Factors and Pairwise Correlation Coefficients for Estimating Multicollinearity in Regression Equations

Panel A: Variance Inflation Factors from Regressions

\begin{tabular}{lcr} 
& Using Original ImpROE Measures & Using Change in Sequentia \\
\cline { 2 - 3 } FINANCE & 1.072 & 1.071 \\
HI-TECH & 1.089 & 1.088 \\
ImpROE(BQ) & 35.704 & 1.597 \\
ImpROE(EAD,-2) & 37.158 & \\
ImpROE(EAD,+2) & 13.045 & \\
ImpROE(EQ) & 11.369 & 1.011 \\
$\Delta$ ImpROE(EAD,-2) & & 1.206 \\
$\Delta$ ImpROE(EAD,+2) & & 1.027 \\
$\Delta$ ImpROE(EQ) & & 1.546 \\
BTM & 1.568 & 1.190 \\
SIZE & 1.192 &
\end{tabular}

\begin{tabular}{|c|c|c|c|c|c|c|}
\hline & $\operatorname{ImpROE(BQ)}$ & $\operatorname{ImpROE}(\mathrm{EAD},-2)$ & $\operatorname{ImpROE}(\mathrm{EAD},+2)$ & $\operatorname{ImpROE(EQ)}$ & BTM & SIZE \\
\hline $\operatorname{ImpROE(BQ)}$ & 1.00 & & & & & \\
\hline $\operatorname{ImpROE}(\mathrm{EAD},-2)$ & 0.97 & 1.00 & & & & \\
\hline $\operatorname{ImpROE}(\mathrm{EAD},+2)$ & 0.81 & 0.82 & 1.00 & & & \\
\hline $\operatorname{ImpROE}(\mathrm{EQ})$ & 0.73 & 0.74 & 0.89 & 1.00 & & \\
\hline BTM & -0.17 & -0.17 & -0.19 & -0.17 & 1.00 & \\
\hline SIZE & 0.10 & 0.09 & 0.10 & 0.08 & -0.29 & 1.00 \\
\hline$\Delta \operatorname{ImpROE}(\mathrm{EAD},-2)$ & -0.03 & 0.21 & 0.11 & 0.11 & -0.01 & -0.02 \\
\hline$\Delta \operatorname{ImpROE}(\mathrm{EAD},+2)$ & -0.40 & -0.43 & 0.17 & 0.13 & -0.01 & 0.00 \\
\hline$\Delta \operatorname{ImpROE}(\mathrm{EQ})$ & -0.12 & -0.12 & -0.18 & 0.28 & 0.03 & -0.05 \\
\hline $\mathrm{ROE}_{\mathrm{Y} 1}$ & 0.01 & 0.01 & 0.02 & 0.04 & 0.03 & -0.04 \\
\hline $\mathrm{ROE}_{\mathrm{Y} 3}$ & -0.02 & -0.02 & -0.02 & 0.02 & 0.06 & -0.07 \\
\hline \multirow[t]{2}{*}{$\mathrm{ROE}_{\mathrm{Y} 5}$} & -0.03 & -0.03 & -0.03 & 0.01 & 0.07 & -0.06 \\
\hline & $\Delta \operatorname{ImpROE}(\mathrm{EAD},-2)$ & $\Delta \operatorname{ImpROE}(\mathrm{EAD},+2)$ & $\Delta \operatorname{ImpROE}(\mathrm{EQ})$ & $\mathrm{ROE}_{\mathrm{Y} 1}$ & $\mathrm{ROE}_{\mathrm{Y} 3}$ & $\mathrm{ROE}_{\mathrm{Y} 5}$ \\
\hline$\Delta \operatorname{ImpROE}(\mathrm{EAD},-2)$ & 1.00 & & & & & \\
\hline$\Delta \operatorname{ImpROE}(\mathrm{EAD},+2)$ & -0.17 & 1.00 & & & & \\
\hline$\Delta \operatorname{ImpROE}(\mathrm{EQ})$ & -0.01 & -0.08 & 1.00 & & & \\
\hline $\mathrm{ROE}_{\mathrm{Y} 1}$ & 0.00 & 0.01 & 0.06 & 1.00 & & \\
\hline $\mathrm{ROE}_{\mathrm{Y} 3}$ & 0.00 & 0.01 & 0.08 & 0.19 & 1.00 & \\
\hline $\mathrm{ROE}_{\mathrm{Y} 5}$ & 0.00 & 0.01 & 0.09 & 0.27 & 0.70 & 1.00 \\
\hline
\end{tabular}

Variables are as defined in Table 1. 
Table 3

Pairwise Correlation Coefficients Between ROE and ImpROEs measured at the four different points in the fiscal quarter.

\section{Panel A: POSITIVE ROE SAMPLE}

$\operatorname{ImpROE}(\mathrm{BQ})$

$\operatorname{ImpROE}(\mathrm{EAD},-2)$

$\operatorname{ImpROE}(\mathrm{EAD},+2)$

$\operatorname{ImpROE}(\mathrm{EQ})$

$\mathrm{ROE}_{\mathrm{Y} 1}$

$\mathrm{ROE}_{\mathrm{Y} 3}$

$\mathrm{ROE}_{\mathrm{Y} 5}$

\begin{tabular}{c}
$\operatorname{ImpROE}(\mathrm{BQ})$ \\
\hline 1.000 \\
0.989 \\
0.865 \\
0.849 \\
0.450 \\
0.410 \\
0.357
\end{tabular}

\section{Panel B: NEGATIVE ROE SAMPLE}

$\operatorname{ImpROE}(\mathrm{BQ})$

$\operatorname{ImpROE}(\mathrm{EAD},-2)$

$\operatorname{ImpROE}(\mathrm{EAD},+2)$

$\operatorname{ImpROE}(\mathrm{EQ})$

$\mathrm{ROE}_{\mathrm{Y} 1}$

$\mathrm{ROE}_{\mathrm{Y} 3}$

ROE $_{Y 5}$

1.000
0.985
0.844
0.824
-0.246
-0.311
-0.330

$\operatorname{ImpROE}(\mathrm{EAD},-2)$

1.000
0.865
0.848
0.453
0.411
0.360

1.000
0.865

0.848

0.453

0.360

1.000
0.847
0.825
-0.243
-0.312
-0.333

$\operatorname{ImpROE}(\mathrm{EAD},+2)$

$\begin{array}{ll}1.000 & \\ 0.956 & 1.000 \\ 0.486 & 0.503 \\ 0.445 & 0.462 \\ 0.387 & 0.403\end{array}$

Variables are as defined in Table 1. 
Table 4

Results of Fama-McBeth Tests (with Newey-West adjustment) of the Relationship Between ImpROE at different intervals and Future ROEs.

Results for the First Fiscal Quarter (where annual earnings of previous fiscal year are disclosed)

\begin{tabular}{|c|c|c|c|c|c|c|c|c|c|}
\hline & \multicolumn{3}{|c|}{$\mathrm{ROE}_{\mathrm{Y} 1}$ as dependent variable } & \multicolumn{3}{|c|}{$\underline{\mathrm{ROE}}_{\mathrm{Y} 3}$ as dependent variable } & \multicolumn{3}{|c|}{$\underline{\mathrm{ROE}}_{\mathrm{Y} 5}$ as dependent variable } \\
\hline & $\underline{\text { Coefficient }}$ & t-value & probability & $\underline{\text { Coefficient }}$ & t-value & probability & $\underline{\text { Coefficient }}$ & t-value & probability \\
\hline \multicolumn{10}{|c|}{ Panel A: POSITIVE ROE firms } \\
\hline Intercept & 0.131 & 3.40 & $* * *$ & 0.246 & 5.33 & $* * *$ & 0.332 & 4.42 & $* * *$ \\
\hline FINANCE & 0.022 & 2.05 & $*$ & 0.037 & 2.81 & $* *$ & 0.055 & 2.51 & $* *$ \\
\hline HI-TECH & -0.026 & -2.01 & $*$ & -0.021 & -1.33 & & -0.016 & -0.62 & \\
\hline $\operatorname{ImpROE}(\mathrm{BQ})$ & 0.282 & 13.15 & $* * *$ & 0.312 & 11.92 & $* * *$ & 0.327 & 7.40 & $* * *$ \\
\hline$\Delta \operatorname{ImpROE}(\mathrm{EAD},-2)$ & 0.378 & 3.56 & $* * *$ & 0.457 & 3.48 & $* * *$ & 0.508 & 2.25 & $*$ \\
\hline$\Delta \operatorname{ImpROE}(\mathrm{EAD},+2)$ & 0.331 & 5.68 & $* * *$ & 0.402 & 5.79 & $* * *$ & 0.466 & 4.01 & $* * *$ \\
\hline$\triangle \mathrm{ImpROE}(\mathrm{EQ})$ & 0.320 & 4.04 & $* * *$ & 0.353 & 3.67 & $* * *$ & 0.276 & 1.65 & \\
\hline BTM & -0.045 & -3.07 & $* * *$ & -0.061 & -3.32 & $* * *$ & -0.080 & -2.66 & $* *$ \\
\hline SIZE & -0.001 & -0.25 & & -0.008 & -2.63 & $* *$ & -0.012 & -2.48 & $*$ \\
\hline Adjusted R-squared ( & (rage) & 0.329 & & & 0.276 & & & 0.229 & \\
\hline Total sample size & & 34,238 & & & 25,973 & & & 19,947 & \\
\hline \multicolumn{10}{|c|}{ Panel B: NEGATIVE ROE firms } \\
\hline Intercept & -0.503 & -2.54 & $* * *$ & -0.433 & -2.95 & $* *$ & -0.465 & -2.03 & $*$ \\
\hline FINANCE & 0.019 & 0.23 & & 0.013 & 0.20 & & -0.003 & -0.02 & \\
\hline HI-TECH & 0.021 & 0.39 & & 0.036 & 0.94 & & 0.037 & 0.63 & \\
\hline $\operatorname{ImpROE(BQ)}$ & -0.323 & -3.62 & $* * *$ & -0.298 & -4.60 & $* * *$ & -0.265 & -2.61 & $* *$ \\
\hline$\Delta \operatorname{ImpROE}(\mathrm{EAD},-2)$ & -0.260 & -0.60 & & -0.413 & -1.32 & & -0.562 & -1.18 & \\
\hline$\Delta \operatorname{ImpROE}(\mathrm{EAD},+2)$ & -0.658 & -2.94 & $* *$ & -0.528 & -3.28 & $* * *$ & -0.425 & -1.66 & $\&$ \\
\hline$\Delta \operatorname{ImpROE}(\mathrm{EQ})$ & 0.017 & 0.05 & & -0.113 & -0.44 & & -0.197 & -0.49 & \\
\hline BTM & -0.005 & -0.09 & & 0.046 & 1.11 & & 0.080 & 1.17 & \\
\hline SIZE & 0.028 & 1.93 & $\&$ & 0.024 & 2.18 & $*$ & 0.025 & 1.47 & $\&$ \\
\hline \multirow{2}{*}{\multicolumn{2}{|c|}{$\begin{array}{l}\text { Adjusted R-squared (average) } \\
\text { Total sample size }\end{array}$}} & 0.172 & & & 0.230 & & & 0.217 & \\
\hline & & 8,936 & & & 6,842 & & & 4,624 & \\
\hline
\end{tabular}

Variables are as defined in Table $1 . \&, *, * *, * *$ denote significant at probability of less than $0.1,0.05,0.01$, and 0.001 , respectively. 
Table 5

Results of Fama-McBeth Tests (with Newey-West adjustment) of the Relationship Between ImpROE at different intervals and Future ROEs. Results for the Fourth Fiscal Quarter (where annual earnings of previous fiscal year are disclosed)

\begin{tabular}{|c|c|c|c|c|c|c|c|c|c|}
\hline \multirow{3}{*}{ Panel A: POSITIVE ROE firı } & \multicolumn{3}{|c|}{$\underline{\mathrm{ROE}}_{\mathrm{Y} 1}$ as dependent variable } & \multicolumn{3}{|c|}{$\underline{\mathrm{ROE}}_{\mathrm{Y} 3}$ as dependent variable } & \multicolumn{3}{|c|}{$\underline{\mathrm{ROE}}_{\mathrm{Y} 5}$ as dependent variable } \\
\hline & $\underline{\text { Coefficient }}$ & $\underline{\mathrm{t} \text {-value }}$ & probability & $\underline{\text { Coefficient }}$ & $\underline{t \text {-value }}$ & probability & Coefficient & $\underline{\mathrm{t} \text {-value }}$ & $\underline{\text { Probability }}$ \\
\hline & & & & & & & & & \\
\hline Intercept & 0.126 & 2.92 & $* * *$ & 0.238 & 4.80 & $* * *$ & 0.313 & 3.82 & $* * *$ \\
\hline FINANCE & 0.022 & 1.69 & $\&$ & 0.036 & 2.35 & $* *$ & 0.060 & 2.25 & $*$ \\
\hline HI-TECH & -0.030 & -2.22 & $*$ & -0.027 & -1.68 & $\&$ & -0.014 & -0.51 & \\
\hline $\operatorname{ImpROE}(\mathrm{BQ})$ & 0.295 & 12.67 & $* * *$ & 0.313 & 11.10 & $* * *$ & 0.339 & 7.17 & $* * *$ \\
\hline$\Delta \operatorname{ImpROE}(\mathrm{EAD},-2)$ & 0.347 & 2.35 & $*$ & 0.428 & 2.36 & $*$ & 0.526 & 1.71 & $\&$ \\
\hline$\Delta \operatorname{ImpROE}(\mathrm{EAD},+2)$ & 0.330 & 5.13 & $* * *$ & 0.409 & 5.24 & $* * *$ & 0.398 & 3.02 & $* * *$ \\
\hline$\Delta \operatorname{ImpROE}(\mathrm{EQ})$ & 0.285 & 3.74 & $* * *$ & 0.331 & 3.67 & $* * *$ & 0.294 & 1.92 & $\&$ \\
\hline BTM & -0.037 & -2.28 & $* * *$ & -0.055 & -2.97 & $* *$ & -0.069 & -2.20 & $*$ \\
\hline SIZE & -0.001 & -0.26 & & -0.007 & -2.27 & $*$ & -0.012 & -2.14 & $*$ \\
\hline Adjusted R-squared (average) & & 0.3042 & & & 0.2637 & & & 0.2223 & \\
\hline Total sample size & & 35,253 & & & 26,746 & & & 20,454 & \\
\hline \multicolumn{10}{|c|}{ Panel B: NEGATIVE ROE firms } \\
\hline Intercept & -0.462 & -2.21 & $*$ & -0.354 & -2.33 & $* *$ & -0.418 & -1.80 & $\&$ \\
\hline FINANCE & 0.010 & 0.11 & & 0.031 & 0.39 & & -0.012 & -0.09 & \\
\hline HI-TECH & 0.006 & 0.11 & & 0.016 & 0.40 & & 0.022 & 0.39 & \\
\hline $\operatorname{ImpROE}(\mathrm{BQ})$ & -0.336 & -3.59 & $* * *$ & -0.298 & -4.49 & $* * *$ & -0.298 & -3.03 & $* * *$ \\
\hline$\Delta \operatorname{ImpROE}(\mathrm{EAD},-2)$ & 0.017 & 0.03 & & -0.297 & -0.78 & & -0.271 & -0.50 & \\
\hline$\Delta \operatorname{ImpROE}(\mathrm{EAD},+2)$ & -0.627 & -2.67 & $* *$ & -0.450 & -2.65 & $* *$ & -0.498 & -2.05 & $*$ \\
\hline$\Delta \operatorname{ImpROE}(\mathrm{EQ})$ & 0.286 & 0.90 & & -0.005 & -0.02 & & -0.136 & -0.43 & \\
\hline BTM & -0.037 & -0.67 & & 0.024 & 0.57 & & 0.062 & 0.92 & \\
\hline SIZE & 0.026 & 1.72 & $\&$ & 0.018 & 1.65 & $\&$ & 0.022 & 1.30 & \\
\hline Adjusted R-squared (average) & & 0.1724 & & & 0.2093 & & & 0.2323 & \\
\hline Total sample size & & 9,041 & & & 7,211 & & & 5,045 & \\
\hline
\end{tabular}

Variables are as defined in Table 1. \&, *,**,** denote significant at probability of less than 0.1, 0.05, 0.01, and 0.001, respectively. 
Table 6

Results of Fama-McBeth Tests (with Newey-West adjustment)of the Relationship Between ImpROE at different Intervals and Future ROEs Results for the Large and Small Firms (First Quarter Only) - One Year Ahead ROE Forecasts

\begin{tabular}{|c|c|c|c|c|c|c|}
\hline \multirow[b]{3}{*}{ Panel A: POSITIVE ROE firn } & \multicolumn{3}{|c|}{ LARGE FIRMS Sample } & \multicolumn{3}{|c|}{ SMALL FIRMS Sample } \\
\hline & coefficient & $\mathrm{t}$-value & Probability & coefficient & t-value & Probability \\
\hline & & & & & & \\
\hline Intercept & 0.108 & 1.39 & & 0.448 & 4.01 & $* * *$ \\
\hline FINANCE & 0.022 & 1.49 & & 0.023 & 1.08 & \\
\hline HI-TECH & -0.032 & -1.46 & & -0.024 & -1.10 & \\
\hline $\operatorname{ImpROE}(\mathrm{BQ})$ & 0.292 & 8.66 & $* * *$ & 0.202 & 5.03 & $* * *$ \\
\hline$\Delta \operatorname{ImpROE}(\mathrm{EAD},-2)$ & 0.202 & 1.09 & & 0.307 & 1.81 & $\&$ \\
\hline$\Delta \operatorname{ImpROE}(\mathrm{EAD},+2)$ & 0.283 & 3.22 & $* * *$ & 0.220 & 2.29 & $* * *$ \\
\hline$\Delta \operatorname{ImpROE}(\mathrm{EQ})$ & 0.320 & 2.82 & $* *$ & 0.287 & 2.02 & $* *$ \\
\hline BTM & -0.093 & -3.28 & $* * *$ & -0.092 & -4.01 & $* * *$ \\
\hline SIZE & 0.003 & 0.60 & & -0.023 & -2.58 & $* *$ \\
\hline Adjusted R-squared (average) & & 0.3767 & & & 0.231 & \\
\hline Total sample size & & 17,151 & & & 15,301 & \\
\hline \multicolumn{7}{|c|}{ Panel B: NEGATIVE ROE firms } \\
\hline Intercept & -0.572 & -0.99 & & -0.851 & -2.32 & $*$ \\
\hline FINANCE & 0.025 & 0.18 & & -0.008 & -0.07 & \\
\hline HI-TECH & 0.055 & 0.51 & & 0.028 & 0.40 & \\
\hline $\operatorname{ImpROE}(\mathrm{BQ})$ & -0.108 & -0.55 & & -0.234 & -2.07 & $*$ \\
\hline$\Delta \operatorname{ImpROE}(\mathrm{EAD},-2)$ & -0.198 & -0.19 & & -0.190 & -0.36 & \\
\hline$\Delta \operatorname{ImpROE}(\mathrm{EAD},+2)$ & 0.037 & 0.09 & & -0.332 & -1.31 & \\
\hline$\Delta \operatorname{ImpROE}(\mathrm{EQ})$ & -0.247 & -0.34 & & 0.179 & 0.40 & \\
\hline BTM & 0.125 & 1.09 & & 0.063 & 1.00 & \\
\hline SIZE & 0.021 & 0.51 & & 0.051 & 1.64 & $\&$ \\
\hline Adjusted R-squared (average) & & 0.244 & & & 0.148 & \\
\hline Total sample size & & 3,138 & & & 5,800 & \\
\hline
\end{tabular}

Variables are as defined in Table 1. \&, *,**,*** denote significant at probability of less than 0.1, 0.05, 0.01, and 0.001, respectively. 


\section{CONCLUSIONS}

We have proposed a new method to assess the usefulness of information that focuses on its inferential value. Inferential value is defined as the extent to which capital-market investors can draw inferences from information that correctly anticipates future firm performance. We have evaluated the relative inferential value of accounting quarterly earnings releases versus information that arrives during non-earnings announcement periods. For the present purpose, firm performance was defined in terms of accounting profitability assessed as the rate of return on equity. Empirically, we used the residual income model (RIM), given price and an estimated cost of capital, to compute a market-based estimate of future Returns on Equity (ROE). Given the estimates of ROE, we examined how well the estimate predicts future ROE. Our findings suggest that quarterly accounting earnings releases have relatively higher inferential value than does information that arrives during interim periods. However, our results also suggest that investors generally do not correctly anticipate future losses. In other words, losses in operations (or attributable to asset write-downs and extraordinary items) are not so well predicted in advance. For firms with sustained profitable operations, the results suggest that despite the richer information environment available for large firms, earnings announcements remain as important in anticipating future profitability for them as for smaller firms with their poorer information environment.

The findings from this study suggest one avenue for future research. Although short-term price reactions have been one of the primary means of evaluating the usefulness of accounting disclosures, the method developed in this paper may be beneficially applied to determining the relative inferential value of these disclosures. Accounting policies that provide investors with the means to evaluate managerial competence and allow for intelligent adaptation to changing economic conditions must be evaluated against other alternatives. The inferential-value approach proposed in this paper provides one possible means of performing such an evaluation.

\section{ACKNOWLEDGEMENT}

This research was made possible by financial assistance from the Rutgers Center for Governmental Education and Research. The financial databases were provided through the Whitcomb Center for Research in Financial Services at the Rutgers Business School. An earlier version of this paper was presented at the 16th International Symposium on Forecasting held in Istanbul, Turkey and the 2008 Oxford Business and Economics Conference in London, England.

\section{AUTHOR INFORMATION}

C. Catherine Chiang received her Ph.D. from City University of New York (CUNY), Master of Accounting from University of North Carolina at Chapel Hill and M.S. in Management from North Carolina State University. Prior to her employment at Elon, she taught at CUNY- Baruch College, Greensboro College, and North Carolina Central University. She has published articles in Journal of Accounting and Public Policy, Review of Quantitative Finance and Accounting, among others. She serves on the Editorial Board of International Journal of Organizational Innovation. Her research focuses on the capital market valuation of financial reports, especially the valuation of intangible assets.

Yaw M. Mensah is currently the Senior Associate Dean for Faculty and Research Director of the Center for Governmental Accounting Education and Research at the Rutgers Business School - Newark and New Brunswick. $\mathrm{He}$ is also a Professor of Accounting at Rutgers, The State University of New Jersey. His research interests and publications have spanned the areas of accounting (international, managerial, financial, and governmental and nonprofit), and economics (efficiency measurement and analysis).

\section{REFERENCES}

1. Atiase, R. (1980). Predisclosure information asymmetries, firm capitalization, financial reports, and security price behavior. Unpublished Ph.D. thesis. Berkeley, CA: University of California.

2. Atiase, R. (1985). Predisclosure information, firm capitalization and security price behavior around earnings announcements. Journal of Accounting Research, (Spring), 21-35. 
3. Belsely, D., E. Kuh, and R. Welsch (1980). Regression Diagnostics: Identifying Influential Data and Sources of Collinearity. New York: John Wiley and Sons.

4. Collins, D. W., S. P. Kothari, and J. D. Rayburn (1987). Firm size and the information content of prices with respect to earnings. Journal of Accounting and Economics, 9 (July), 111-138.

5. Darrough, Masako N. and Ye, Jianming (2007). Valuation of Loss Firms in a Knowledge-based Economy. Review of Accounting Studies, 12(1), 61-93.

6. Doyle, J. T., R. J. Lundholm, and M. Soliman (2003). The predictive value of expenses excluded from "Pro Forma" earnings. Review of Accounting Studies, 8(2-3), 145-174.

7. Easton, P. D., T. S. Harris and J. A. Ohlson (1992). Aggregate accounting earnings can explain most of security returns: The case of long return intervals. Journal of Accounting and Economics, 15 (June/September), 119-142.

8. Fama E. and K. French (1992). The cross-section of expected stock returns. Journal of Finance, 47 (June), 427-465.

9. Fama E. and K. French (1995). Size and book-to-market factors in earnings and returns. Journal of Finance, 50 (March), 131-155.

10. Foster, G. (1977). Quarterly accounting data: Time series properties and predictive-ability results. The Accounting Review, 59 (January), 71-83.

11. Francis, J. and K. Schipper (1999). Have financial statements lost their relevance? Journal of Accounting Research, 37, 319-352.

12. Gode, D. and P. Mohanram (2003). What affects the implied cost of equity capital? Review of Accounting Studies, 8(4), 399-431.

13. Kim, D. (1995). The errors-in-variables problem in the cross-section of expected stock returns. Journal of Finance, 50 (December), 1605-1634.

14. Kothari, S. P. (2001). Capital markets research in accounting. Journal of Accounting and Economics, 31, 105-231.

15. Lee, C. M. C., J. Myers, and B. Swaminathan (1999). What is the intrinsic value of the Dow? Journal of Finance, 54, 1693-1741.

16. Lev, B. and P. Zarowin (1999). The boundaries of financial reporting and how to extend them. Journal of Accounting Research, 37, 353--385.

17. McCallig, J. (2003). Revenue Investment, accounting conservatism and the valuation of loss-making firms. $14^{\text {th }}$ Annual Conference on Financial Economics and Accounting. Retrieved April 2, 2009, from SSRN: http://ssrn.com/abstract $=488105$

18. Ohlson, J. A. (1995). Earnings, book values and dividends in equity valuation. Contemporary Accounting Research, 11 (Spring), 1-19.

19. Ohlson, J. A., and B. E. Juettner-Nauroth (2005). Expected EPS and EPS growth as determinants of value. Review of Accounting Studies, 10(2-3), 349-365.

20. Ou, J. and S. Penman (1989). Accounting measurement, price-earnings ratios, and the information content of security prices. Journal of Accounting Research, (Supplement), 111-144.

21. Tobin, J. (1969). A general equilibrium approach to monetary theory. Journal of Money, Credit and Banking, 1 (February), 15-29.

22. Verbeek, M. (2000). A Guide to Modern Econometrics. New York: John Wiley and Sons.

23. Wernerfelt, B. and C. A. Montgomery (1988). Tobin's q and the importance of focus in firm performance. The American Economic Review, 78 (March), 246-250. 